\title{
THE PROTECTIVE AND TOXIC EFFECT OF CERTAIN MINERAL SALTS ON PALM FROND BEETLE, ENNEADESMUS TRISPINOSUS OLIV. (COLEOPTERA: BOSTRYCHIDAE)
}

\author{
M. A. Batt and M. H. Ramadan \\ Plant Protection Research Institute, Agricultural Research Center, Dokki, Giza, Egypt.
}

Received: Aug. 30, 2017

Accepted: Sep. 24,2017

\begin{abstract}
The effectiveness of some mineral salts, as wood preservative, against Palm powder post beetle, Enneadesmus trispinosus Oliv., were studied under laboratory conditions. The obtained results detected that sodium fluoride and copper sulfate are good materials for protection palm fronds from the infestation by bostrychid beetle, E. trispinosus. Dipping technique of palm fronds cutting revealed high toxic effect and complete protection against palm frond beetle, E. trispinosus, at the concentration $8 \%\left(8 \times 10^{4} \mathrm{ppm}\right)$ of sodium fluoride gave $100 \%$ protection, while copper sulfate appeared $100 \%$ reduction at concentration $12 \%(12 x$ $10^{4} \mathrm{ppm}$ ). The lost wood weight resulting from infested cuttings with this borer was decreased with increasing the salt concentration, the percentages of loss wood of palm fronds was $9.05 \%$ at concentration of $0.8 \%$ of sodium fluoride, and was $29.49 \%$ at the concentration of $0.25 \%$ sodium fluoride. As well as, the percentage of lost wood weight was $9.17 \%$ at the concentration of $12 \%$ of copper sulfate, and $30.34 \%$ at the concentration of $0.25 \%$ of copper sulfate.
\end{abstract}

Key words: Enneadesmus trispinosus - mineral salts - sodium fluoride - copper sulfate

\section{INTRODUCTION}

Palm fronds are used nowadays in some places in different governorates for several purposes as popular furniture, desks, chairs, tables, boxes, seats, cages, fencing and other domestic uses.

The collective fronds at manufactories instituted for making different popular furniture are liable to infestation with bostrychid powder post beetle, Enneadesmus trispinosus Oliv., causing intensive damage and loss of infested things (Materials) as shown in Photo (1).

In Egypt some articles were published on powder post beetles such as: Helal and ElSebay (1981), Abd-Allah and Tadrous (1995), Batt et al. (1996), Batt and Girgis (1996), Haggag and Batt (2000) and Batt and Ahmed (2013). Also, other works carried out on the effect of inorganic salts on some insects, such as, Gay et al., (1958) and Pantua, (1965) who demonstrated that the boric acid protected some timber kinds and chip-board effectively against several termite species, whereas Kerner and Becker (1969) reported that fluoride compound gave the best control against the termite Kalotermes spp., Heterotermes spp., Reticulitermes spp. and Comptotermes spp., while Chen et al. (1986) stated that the toxic dosage of copper compound prevent feeding of termite on treated wood and protect nearby untreated wood.

In some studies, El- Sabay (1995), revealed that vacuum impregnation of wood by $4 \%$ boric acid equivalent (BAE) $117 \mathrm{ppm}$ of borone element is the most effective technique against wood borers ( Lyctus africanus and Sinoxylon sudanicum). The recommended concentration gave 100\% mortality for new infestation and over years of protection. Abdel Nur (1980) showed that the brushing and dipping wood treatments in chemicals such as creosote oil and chromated copper arsenate (CCA) afforded the tested timber protection for up to eight years. Whereas, Abd El-Latif et al. (2014) at Fayoum governorate found that the wood preservative chromated copper arsenate (CCA) led to prevent the infestation to Poinciana, willow, mulberry, casuarinas and poplar wood against Psammotermes hybostoma Desneux termite for 2 years. 


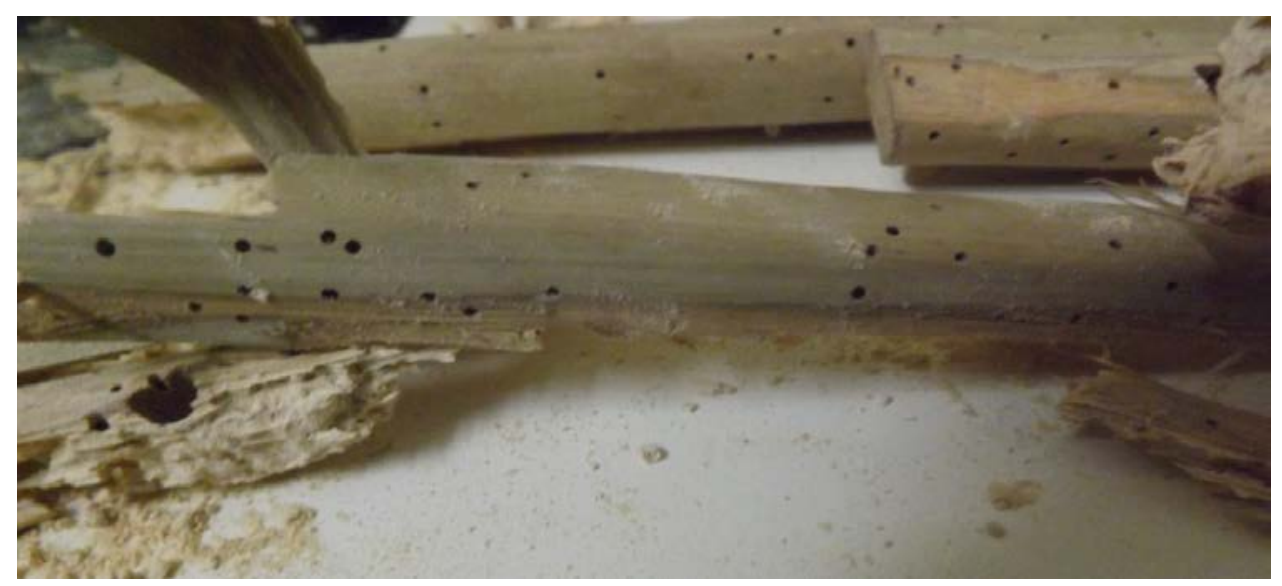

Photo (1). Exit holes of Enneadesmus trispinosus beetles on palm fronds infested

The current work aimed to study the protective and toxic effect of sodium fluoride and copper sulfate on palm frond beetle, $E$. trispinosus, as well as determination of lost wood weight (Consumed wood by beetles and larvae).

\section{MATERIALS AND METHODS}

Infested cuttings of palm fronds with Enneadesmus trispinosus Oliv. beetles were collected from infested fronds at Shanawan village, Shebin El-Kom district, Menoufia governorate and transferred to laboratory of wood borer and termites department, Plant Protection Research Institute, ARC., at Giza governorate. These cuttings were kept in cylindrical plastic containers $(80 \mathrm{~cm}$ height and $45 \mathrm{~cm}$ diameters) covered with muslin cloth. Continued observation was conducted until the beetles emerged.

Stock solution for each mineral salt \{sodium fluoride (NaF) and copper sulfate (CuSo 4$)\}$ was made. For this purpose, 20 grams of each salt were dissolved in $100 \mathrm{ml}$ distilled water to obtain the concentration of $20 \times 10^{4} \mathrm{ppm}$. of each mineral salt, then the chosen concentrations $0.25,0.50,1,2,4,6$ and $8 \%$ for Sodium Fluoride and concentrations $0.25,0.50,1,2,4,6,8,10$ and $12 \%$ for Copper Sulfate were prepared.

Intact cuttings of palm fronds were collected from frond factories at Shanawan village and prepared at $15 \mathrm{~cm}$ length and 2.5 - $3 \mathrm{~cm}$ thickness. These cuttings were left under laboratory conditions of $28.4^{\circ} \mathrm{C}$ average temperature and $44.6 \% \mathrm{RH}$ in wired cages.

The cuttings were grouped of each 10 cuttings. Ten cuttings (as replicates) for each concentration of each mineral salts were dipped in different concentrations of each mineral salts solutions for 5,10 \&15 minutes and left in laboratory air for 48 hours to dryness. Each cutting was kept in glass jar $(18 \mathrm{~cm} \times 7 \mathrm{~cm})$ and exposed to 10 couples (male \& female) of tested insect; these Jars were covered with muslin clothes and fixed with rubber bands. Ten untreated cuttings were used as check.

Continuous observation was made to record the mortality beetles, number of entrance holes and the number of emerged beetles after infestation (for one generation). The reduction percentages were counted according by Abbott's formula (1925).

To determine the effect of mineral salts on weight of lost wood each ten intact fronds were prepared at $15 \mathrm{~cm}$ length and $2.5-3$ $\mathrm{cm}$ thickness and dipped for 15 minute in each concentration of two tested salts. The cuttings were left for dryness for 48 hours in laboratory and weighted then each cutting was kept in glass jar $(18 \mathrm{~cm} \times 7 \mathrm{~cm})$ and exposed to 10 couples (male \& female) of 
tested insect, these Jars were covered with muslin clothes and fixed with rubber bands. The cuttings were weighted after emergence of beetles. Also, ten untreated cuttings were exposed for 10 couples of beetles used as check. Beside 10 intact cutting without treatment and beetles to determine moisture content.

The statistical analysis for obtained results was carried out by SAS program (2001).

\section{RESULTS AND DISCUSSION}

\section{A. Effect of mineral salts on the infestation}

\section{1-Effect of sodium fluoride}

Data on the effect of sodium fluoride on infestation of palm frond cuttings with E.trispinosus Olive. by dipping technique are illustrated in Table (1).

The mortality percentage of $E$. trispinosus beetles exposed to palm frond cuttings treated with sodium fluoride at different concentrations appeared that the highest mortality percentage was $100 \%$, recorded for concentration $8 \%$,while the lower concentration $0.25 \%$ showed the least mortality percentage $2-5 \%$, after 3 days, $11-18 \%$ after 7 days and $24-28 \%$ after 14 days. The obtained data clearly showed that the mortality percentages increased with the increase of immersing time $(5,10$ and 15 min.) of date palm fronds in different concentrations of salt solutions.

In this respect, the number of entrance and emergence holes decreased with the increase of salt solution concentration. The reduction percentage for each entrance and emergence beetles was $100 \%$ at concentration of $8 \times 10^{4} \mathrm{ppm}$, while the reduction values ranged between 8.14 $11.63 \%$ and $5.79-10.09 \%$ for number of entrance and emergence holes at concentration of $0.25 \times 10^{4} \mathrm{ppm}$, respectively.

The obtained results agree with those of Moein and Farrag (1997) who stated that the sodium fluoride at $0.5 \%$ and $5 \%$ concentration gave $6.67 \%$ and $43.33 \%$ mortality of Cryptoterms brevis Walk termite, respectively. after two days of exposure, while after 21 days the concentrations induced $100 \%$ mortality, except $0.5 \%$ concentration performed to $88.89 \%$ mortality. Also, Mohamad (2013) on Luctus linearis Goeze, found that the $4 \%$ and $8 \%$ concentrations of the sodium fluoride salt gave $80 \%$ and $90 \%$ mortalities .respectively, with no emerged beetles.

Statistical analysis for the obtained values Table (5) on the effect of sodium fluoride salt on mortality percentages, reduction of entrance holes and reduction of emergence holes, indicated that there were high significant effect between each of concentration of salts, days of death and percentage of mortality $(P=0.0001)$, while insignificant effect between immersing time and $\%$ mortality $(P=0.1390)$; the explained variance detected the effective percent for these variables was $85.99 \%$.

The effect of concentrations appeared also high significant effect on the percentage of reduction on each entrance and emergence holes $(P=0.0001)$, while the immersing time was insignificant of the $\%$ of reduction on each entrance and emergence holes $(P=0.2847$ and 0.2202$)$ respectively. Whereas the explained variance recorded $91.97 \%$ and $89.67 \%$, respectively.

\section{2- Effect of copper sulfate:}

Data in Table (2) show the effect of copper sulfate on infestation of palm frond cuttings with $E$. trispinosus beetles.

The highest mortality percentage of $E$. trispinosus beetle (100\%) was recorded on palm frond cuttings treated with copper sulfate at $12 \%$ concentration, while the lowest percentages were (1-4\%), (8-12\%) and (21-25\%) after 3,7 and 14days exposure, recorded for $0.25 \%$ concentration.

The palm frond cuttings which dipped in various concentrations of copper sulfate 
solution for different periods $(5,10$ and 15min) appeared clear effect on each of the mortality percentages, reduction percentages of entrance holes and of emerged beetles. The highest reduction was $100 \%$ recorded of each entrance and emergence holes at the concentration $12 \mathrm{x}$
$10^{4} \mathrm{ppm}$ at different immersing times, while the lowest percentage of reduction recorded $2.41-4.82 \%$ for entrance holes and between $3.70-5.56 \%$ for emergence holes at the concentration $0.25 \times 10^{4} \mathrm{ppm}$ at different immersing times.

Table (1): Effect of sodium fluoride on infestation of palm frond cuttings with Enneadesmus trispinosus beetles.

\begin{tabular}{|c|c|c|c|c|c|c|c|c|}
\hline \multirow{2}{*}{\begin{tabular}{|c|} 
Conc. \\
$\begin{array}{c}\text { Percent } \\
\text { (ppm) }\end{array}$
\end{tabular}} & \multirow{2}{*}{$\begin{array}{l}\text { Immersing } \\
\text { time } \\
(\min )\end{array}$} & \multicolumn{3}{|c|}{$\begin{array}{c}\text { Mortality } \\
\text { percentages on } \\
\text { various days }\end{array}$} & \multicolumn{2}{|c|}{$\begin{array}{c}\text { Number of entrance } \\
\text { holes }\end{array}$} & \multicolumn{2}{|c|}{$\begin{array}{c}\text { Number of emergence } \\
\text { holes }\end{array}$} \\
\hline & & 3 & 7 & 14 & Mean \pm Sd & $\begin{array}{c}\text { Reduction } \\
\%\end{array}$ & Mean \pm Sd & $\begin{array}{c}\text { Reduction } \\
\%\end{array}$ \\
\hline \multirow{3}{*}{$\begin{array}{c}0.25 \\
\left(0.25 \times 10^{4}\right)\end{array}$} & 5 & 2 & 11 & 24 & $7.9 \pm 0.34$ & 8.14 & $43.9 \pm 0.32$ & 5.79 \\
\hline & 10 & 3 & 13 & 25 & $7.8 \pm 0.28$ & 9.30 & $43.3 \pm 0.28$ & 7.08 \\
\hline & 15 & 5 & 18 & 28 & $7.6 \pm 0.22$ & 11.63 & $41.9 \pm 0.44$ & 10.09 \\
\hline \multirow{3}{*}{$\begin{array}{c}0.50 \\
\left(0.50 \times 10^{4}\right)\end{array}$} & 5 & 7 & 26 & 58 & $6.4 \pm 0.39$ & 25.58 & $38.5 \pm 0.39$ & 17.38 \\
\hline & 10 & 9 & 28 & 59 & $6.2 \pm 0.35$ & 27.91 & $36.6 \pm 0.31$ & 21.46 \\
\hline & 15 & 13 & 31 & 63 & $5.8 \pm 0.23$ & 32.56 & $33.9 \pm 0.25$ & 27.25 \\
\hline \multirow{3}{*}{$\begin{array}{c}1 \\
\left(1 \times 10^{4}\right)\end{array}$} & 5 & 21 & 54 & 68 & $5.4 \pm 0.34$ & 37.21 & $31.7 \pm 0.37$ & 31.97 \\
\hline & 10 & 23 & 56 & 70 & $5.1 \pm 0.29$ & 40.70 & $29.8 \pm 0.31$ & 36.05 \\
\hline & 15 & 26 & 59 & 73 & $4.8 \pm 0.23$ & 44.19 & $26.4 \pm 0.25$ & 43.35 \\
\hline \multirow{3}{*}{$\begin{array}{c}2 \\
\left(2 \times 10^{4}\right)\end{array}$} & 5 & 38 & 68 & 86 & $4.1 \pm 0.31$ & 52.33 & $22.3 \pm 0.33$ & 52.15 \\
\hline & 10 & 42 & 71 & 88 & $3.9+0.19$ & 54.65 & $20.2 \pm 0.42$ & 56.65 \\
\hline & 15 & 46 & 74 & 92 & $3.6 \pm 0.28$ & 58.14 & $17.6 \pm 0.25$ & 62.23 \\
\hline \multirow{3}{*}{$\begin{array}{c}4 \\
\left(4 \times 10^{4}\right)\end{array}$} & 5 & 59 & 84 & 100 & $3.0 \pm 0.24$ & 65.12. & $12.5 \pm 0.33$ & 73.18 \\
\hline & 10 & 63 & 86 & 100 & $2.7 \pm 0.19$ & 68.60 & $9.5 \pm 0.26$ & 79.61 \\
\hline & 15 & 68 & 89 & 100 & $2.3 \pm 0.16$ & 73.26 & $7.6 \pm 0.41$ & 83.69 \\
\hline \multirow{3}{*}{$\begin{array}{c}6 \\
\left(6 \times 10^{4}\right)\end{array}$} & 5 & 77 & 96 & 100 & $1.1 \pm 0.17$ & 87.21 & $5.3 \pm 0.17$ & 88.62 \\
\hline & 10 & 81 & 100 & - & $09 \pm 0.25$ & 89.53 & $3.1 \pm 0.25$ & 93.35 \\
\hline & 15 & 84 & 100 & - & $0.5 \pm 0.16$ & 94.19 & $1.1 \pm 0.36$ & 97.64 \\
\hline \multirow{3}{*}{$\begin{array}{c}8 \\
\left(8 \times 10^{4}\right)\end{array}$} & 5 & 100 & - & - & 0.0 & 100 & 0.0 & 100 \\
\hline & 10 & 100 & - & - & 0.0 & 100 & 0.0 & 100 \\
\hline & 15 & 100 & - & - & 0.0 & 100 & 0.0 & 100 \\
\hline Check & - & 0 & 0 & 0 & $8.6 \pm 0.08$ & - & $46.6 \pm 0.66$ & - \\
\hline
\end{tabular}


The protective and toxic effect of certain mineral salts on palm

Table (2): Effect of copper sulfate on infestation of palm frond cuttings with Enneadesmus trispinosus beetles.

\begin{tabular}{|c|c|c|c|c|c|c|c|c|}
\hline \multirow{2}{*}{\begin{tabular}{|c|} 
Conc. \\
$\begin{array}{c}\text { Percent } \\
\text { (ppm) }\end{array}$ \\
\end{tabular}} & \multirow[t]{2}{*}{$\begin{array}{l}\text { Immersing } \\
\text { time } \\
(\min )\end{array}$} & \multicolumn{3}{|c|}{$\begin{array}{l}\text { Mortality } \\
\text { percentages on } \\
\text { various days }\end{array}$} & \multicolumn{2}{|c|}{$\begin{array}{l}\text { Number of entrance } \\
\text { holes }\end{array}$} & \multicolumn{2}{|c|}{$\begin{array}{c}\text { Number of emergence } \\
\text { holes }\end{array}$} \\
\hline & & 3 & 7 & 14 & Mean + Sd. & $\begin{array}{c}\text { Reduction } \\
\%\end{array}$ & Mean + Sd. & $\begin{array}{l}\text { Reduction } \\
\quad \%\end{array}$ \\
\hline \multirow{3}{*}{$\begin{array}{c}0.25 \\
\left(0.25 \times 10^{4}\right)\end{array}$} & 5 & 1 & 8 & 21 & $8.1 \pm 0.31$ & 2.41 & $41.6 \pm 0.37$ & 3.70 \\
\hline & 10 & 2 & 9 & 22 & $8.0 \pm 0.31$ & 3.61 & $41.3 \pm 0.12$ & 4.40 \\
\hline & 15 & 4 & 12 & 25 & $7.9 \pm 0.23$ & 4.82 & $40.8 \pm 0.14$ & 5.56 \\
\hline \multirow{3}{*}{$\begin{array}{c}0.50 \\
\left(0.50 \times 10^{4}\right)\end{array}$} & 5 & 6 & 22 & 34 & $7.7 \pm 0.18$ & 7.23 & $40.4 \pm 0.22$ & 6.48 \\
\hline & 10 & 5 & 24 & 36 & $7.6 \pm 0.24$ & 8.43 & $40.2 \pm 0.11$ & 6.94 \\
\hline & 15 & 8 & 27 & 39 & $7.4 \pm 0.36$ & 10.84 & $39.9 \pm 0.25$ & 7.64 \\
\hline \multirow{3}{*}{$\begin{array}{c}1 \\
\left(1 \times 10^{4}\right)\end{array}$} & 5 & 13 & 36 & 42 & $7.2 \pm 0.34$ & 13.25 & $39.6 \pm 0.17$ & 8.33 \\
\hline & 10 & 15 & 37 & 43 & $7.1 \pm 0.19$ & 14.46 & $39.2 \pm 0.21$ & 9.26 \\
\hline & 15 & 18 & 39 & 48 & $6.9 \pm 0.12$ & 16.87 & $38.1 \pm 0.53$ & 11.81 \\
\hline \multirow{3}{*}{$\begin{array}{c}2 \\
\left(2 \times 10^{4}\right)\end{array}$} & 5 & 22 & 43 & 50 & $6.6 \pm 0.34$ & 20.48 & $37.5 \pm 0.48$ & 13.19 \\
\hline & 10 & 23 & 45 & 52 & $6.4 \pm 0.17$ & 22.89 & $36.9 \pm 0.44$ & 14.58 \\
\hline & 15 & 26 & 48 & 56 & $6.1 \pm 0.26$ & 26.51 & $35.7 \pm 0.67$ & 17.36 \\
\hline \multirow{3}{*}{$\begin{array}{c}4 \\
\left(4 \times 10^{4}\right)\end{array}$} & 5 & 32 & 53 & 68 & $5.7 \pm 0.32$ & 31.33 & $33.3 \pm 0.52$ & 22.92 \\
\hline & 10 & 34 & 56 & 70 & $5.4+0.39$ & 34.94 & $31.9+0.69$ & 26.16 \\
\hline & 15 & 37 & 59 & 74 & $5.1 \pm 0.18$ & 38.55 & $28.8 \pm 0.62$ & 33.33 \\
\hline \multirow{3}{*}{$\begin{array}{c}6 \\
\left(6 \times 10^{4}\right)\end{array}$} & 5 & 41 & 61 & 85 & $4.4 \pm 0.21$ & 46.99 & $25.3 \pm 0.51$ & 41.44 \\
\hline & 10 & 43 & 64 & 88 & $4.2 \pm 0.27$ & 49.40 & $23.7 \pm 0.39$ & 45.14 \\
\hline & 15 & 46 & 68 & 93 & $3.8 \pm 0.34$ & 54.22 & $20.2 \pm 0.48$ & 53.24 \\
\hline \multirow{3}{*}{$\begin{array}{c}8 \\
\left(8 \times 10^{4}\right)\end{array}$} & 5 & 52 & 79 & 100 & $2.5 \pm 0.23$ & 69.88 & $14.9 \pm 0.67$ & 65.51 \\
\hline & 10 & 55 & 81 & 100 & $2.2 \pm 0.27$ & 73.49 & $12.3 \pm 0.73$ & 71.53 \\
\hline & 15 & 58 & 84 & 100 & $1.8 \pm 0.18$ & 78.31 & $10.7 \pm 0.61$ & 75.23 \\
\hline \multirow{3}{*}{$\begin{array}{c}10 \\
\left(10 \times 10^{4}\right)\end{array}$} & 5 & 81 & 100 & - & $1.2 \pm 0.29$ & 85.54 & $8.8 \pm 0.55$ & 79.63 \\
\hline & 10 & 87 & 100 & - & $1 \pm 0.27$ & 87.95 & $7.9 \pm 0.48$ & 81.71 \\
\hline & 15 & 92 & 100 & - & $0.7 \pm 0.19$ & 91.57 & $6.4 \pm 0.51$ & 85.19 \\
\hline \multirow{3}{*}{$\begin{array}{c}12 \\
\left(12 \times 10^{4}\right)\end{array}$} & 5 & 100 & - & - & 0.0 & 100 & 0.0 & 100 \\
\hline & 10 & 100 & - & - & 0.0 & 100 & 0.0 & 100 \\
\hline & 15 & 100 & - & - & 0.0 & 100 & 0.0 & 100 \\
\hline Check & - & 0 & 0 & 0 & $8.3+0.17$ & - & $43.2+0.96$ & - \\
\hline
\end{tabular}


The obtained results on the effectiveness of copper sulfate salt preservative on $E$. trispinosus beetle are agree with Salmen and Sayed (1990) in Kharga, New Valley, Egypt who reported that $10 \%$ insecticidal barriers of copper sulfate or borax inhibited at take of termite Psammotermes hybostoma Desneux for 6-12 months respectively. Whereas, Moein and Farrag (1997) showed that Copper sulfate was the pest effective salt against Cryptoterms brevis Walk, The concentration $0.5 \%$ gave $8.33 \%$ mortality after 2 days and increased to 83.33 after28 days. The highest concentration 5\% induced 68.89 and 100\% mortality after 2 and 21days respectively, also Abd-El-Malak(2002) reported that the increasing concentration of the Copper sulphate salt led to mortality percentage increase of Cryptoterms brevis Walk termite and effected on incubation period and rate of hatchability. While, Mohamad (2013) reported that the highest mortality percentage $(100 \%)$ of Lyctus linearis Goeze was at concentration $\left(10 \times 10^{4} \mathrm{ppm}\right)$ while, the lowest mortality (7\%) recorded at concentration (2x $\left.10^{4} \mathrm{ppm}\right)$ by Copper sulfate salt.

Statistical analysis for obtained values of effect copper sulfate salt on each the percentage of mortality, reduction of entrance holes and reduction of emergence holes, Table (5), indicated to high significant effect between each of concentration of salts, days of death and percentage of mortality $(P=0.0001)$, while significant effect between immersing time and \% mortality was recorded $(P=0.0277)$; the explained variance detected that the effective percent for these variable was $94.76 \%$.

The effect of salt concentration also appeared high significance on the percentage of reduction of each entrance and emergence holes $(P=0.0001)$, as well the immersing time was high significant with the reduction of holes each entrance $(P=$ 0.0021 ). and percentage of reduction for emergence holes $(P=0.0051)$. Whereas, the explained variance recorded $99.22 \%$ and 98.96, respectively.

\section{B. Effect of mineral salts on lost wood weight:}

The lost wood weight by boring and consumed food by beetles and larvae, resulting from cuttings of palm fronds treated with sodium fluoride or copper sulfate salts and infesting by $E$. trispinosus was obviously apparent from the following results:

\section{1- Effect of sodium fluoride}

The lost wood weight of palm frond cuttings treated by sodium fluoride infesting with E. trispinosus beetles, Table (3) showed that the weight of lost wood decreased with increase of concentration of sodium fluoride preservative. The highest loss ratio in weight was $29.49 \%$ recorded for cuttings treated with concentration $0.25 \times 10^{4}$, while the minimum loss ratio was $9.05 \%$ recorded for concentration $8 \times 10^{4}$. In this respect, Mohamad (2013) found that the rate of wood loss by Lyctus linearis Goeze beetle at $4 \%$ and $8 \%$ concentrations of sodium fluoride preservative were $4.9 \%$ and $4.7 \%$, respectively.

Statistical analysis for obtained values of effect sodium fluoride salt (Table 5) showed high significant between concentration and lost wood weight $(P=0.0032)$, the simple regression was negative $(b=-2.5019)$, Table (5).

\section{2-Effect of copper sulfate}

Cuttings of palm fronds treated with copper sulfate salts appeared that the least ratio of lost wood weight $(9.17 \%)$ recorded at concentration $12 \times 10^{4}$, while the highest loss ratio was ( $30.34 \%$ ) recoded when the concentration of copper sulfate was $0.25 \mathrm{x}$ $10^{4}$ Table (4). 
Table (3): Effect of sodium fluoride salt on lost wood weight of palm frond cuttings infesting with Enneadesmus trispinosus beetles.

\begin{tabular}{|l|l|c|c|c|c|}
\hline \multicolumn{2}{|c|}{ Concentration } & \multicolumn{2}{c|}{ Weight of cutting (g) } & \multicolumn{2}{c|}{ Lost wood } \\
\hline Percent & \multicolumn{1}{|c|}{$\mathrm{ppm}$} & $\begin{array}{c}\text { Before } \\
\text { treatment }\end{array}$ & $\begin{array}{c}\text { After treatment } \\
\text { (emergence) }\end{array}$ & $\begin{array}{c}\text { Weight } \\
(\mathrm{g})\end{array}$ & Loss ratio (\%) \\
\hline 0.25 & $0.25 \times 10^{4}$ & 213.22 & 150.35 & 62.87 & 29.49 \\
\hline 0.50 & $0.50 \times 10^{4}$ & 217.54 & 164.57 & 52.97 & 24.35 \\
\hline 1 & $1 \times 10^{4}$ & 209.28 & 169.32 & 39.96 & 19.09 \\
\hline 2 & $2 \times 10^{4}$ & 216.64 & 183.32 & 33.32 & 15.38 \\
\hline 4 & $4 \times 10^{4}$ & 214.15 & 185.84 & 28.31 & 13.22 \\
\hline 6 & $6 \times 10^{4}$ & 218.27 & 194.16 & 24.11 & 11.05 \\
\hline 8 & $8 \times 10^{4}$ & 219.69 & 199.81 & 19.88 & 9.05 \\
\hline Infested cuttings untreated & 216.64 & 149.31 & 67.33 & 31.08 \\
\hline \multicolumn{2}{|c|}{ Moisture content } & 211.82 & 193.18 & 18.64 & 8.80 \\
\hline
\end{tabular}

Table (4): Effect of copper sulfate salt on lost wood weight of palm frond cuttings infesting with Enneadesmus trispinosus beetles.

\begin{tabular}{|l|l|c|c|c|c|}
\hline \multicolumn{2}{|c|}{ Concentration } & \multicolumn{2}{c|}{ Weight of cutting (g) } & \multicolumn{2}{c|}{ Lost wood } \\
\hline Percent & \multicolumn{1}{|c|}{$p$ pm } & $\begin{array}{c}\text { Before } \\
\text { treatment }\end{array}$ & $\begin{array}{c}\text { After treatment } \\
\text { (emergence) }\end{array}$ & $\begin{array}{c}\text { Weight } \\
(\mathrm{g})\end{array}$ & Loss ratio (\%) \\
\hline 0.25 & $0.25 \times 10^{4}$ & 211.15 & 147.08 & 64.07 & 30.34 \\
\hline 0.50 & $0.50 \times 10^{4}$ & 216.35 & 152.47 & 63.88 & 29.53 \\
\hline 1 & $1 \times 10^{4}$ & 213.32 & 152.09 & 61.23 & 28.70 \\
\hline 2 & $2 \times 10^{4}$ & 211.77 & 155.13 & 56.64 & 26.75 \\
\hline 4 & $4 \times 10^{4}$ & 209.11 & 162.22 & 46.89 & 22.42 \\
\hline 6 & $6 \times 10^{4}$ & 214.53 & 176.34 & 38.19 & 17.80 \\
\hline 8 & $8 \times 10^{4}$ & 217.28 & 184.84 & 32.44 & 14.93 \\
\hline 10 & $10 \times 10^{4}$ & 214.25 & 187.36 & 26.89 & 12.55 \\
\hline 12 & $12 \times 10^{4}$ & 217.41 & 197.47 & 19.94 & 9.17 \\
\hline \multicolumn{2}{|l|}{ Infested cuttings untreated } & 218.13 & 151.18 & 66.95 & 30.69 \\
\hline \multicolumn{2}{|l|}{ Moisture content } & 216.54 & 197.82 & 18.72 & 8.65 \\
\hline
\end{tabular}


Table (5): Statistical analysis for obtained values to effect some mineral salts on percentage of mortality, entrance holes, emergence holes and loss wood by Enneadesmus trispinosus beetles

\begin{tabular}{|c|c|c|c|c|c|c|c|}
\hline \multirow{2}{*}{\multicolumn{2}{|c|}{ Variables }} & \multicolumn{2}{|c|}{ Simple regression } & \multicolumn{4}{|c|}{ Partial regression } \\
\hline & & $\mathrm{b}$ & $\mathrm{P}$ & $\mathrm{b}$ & $\mathrm{P}$ & E.V\% & $P$ \\
\hline \multicolumn{8}{|c|}{ Sodium fluoride } \\
\hline \multirow{3}{*}{$\begin{array}{c}\text { Mortality } \\
\text { percentages }\end{array}$} & Concentration & 10.811 & $0.0001^{* *}$ & 12.366 & $0.0001^{\star *}$ & \multirow{3}{*}{85.9} & \multirow{3}{*}{$0.0001^{* *}$} \\
\hline & Immersing time & 0.2571 & $0.8130^{\mathrm{ns}}$ & 0.621 & $0.1390^{\mathrm{ns}}$ & & \\
\hline & Days of death & 2.2236 & $0.0218^{*}$ & 3.644 & $0.0001^{\star \star}$ & & \\
\hline \multirow{2}{*}{$\begin{array}{l}\text { \%Reduction } \\
\text { entrance } \\
\text { holes }\end{array}$} & Concentration & 10.480 & $0.0001^{\star *}$ & 10.463 & $0.0001^{* *}$ & \multirow{2}{*}{91.9} & \multirow{2}{*}{$0.0001^{* *}$} \\
\hline & Immersing time & 0.7374 & $0.6886^{\text {ns }}$ & 0.586 & $0.2847^{\mathrm{ns}}$ & & \\
\hline \multirow{2}{*}{$\begin{array}{c}\text { \%Reduction } \\
\text { emergence } \\
\text { holes }\end{array}$} & Concentration & 11.365 & $0.0001^{* *}$ & 11.365 & $0.0001^{\star *}$ & \multirow{2}{*}{89.7} & \multirow{2}{*}{$0.0001^{* *}$} \\
\hline & Immersing time & 0.7880 & $0.6781^{\mathrm{ns}}$ & 0.788 & $0.2202^{\mathrm{ns}}$ & & \\
\hline $\begin{array}{c}\text { Lost wood } \\
\text { weight }\end{array}$ & Concentration & -2.5019 & $0.0032^{\star *}$ & \multicolumn{4}{|c|}{--} \\
\hline \multicolumn{8}{|c|}{ Copper sulfate } \\
\hline \multirow{3}{*}{$\begin{array}{c}\text { Mortality } \\
\text { percentages }\end{array}$} & Concentration & 7.3171 & $0.0001^{* *}$ & 8.015 & $0.0001^{\star \star}$ & \multirow{3}{*}{94.7} & \multirow{3}{*}{$0.0001^{* *}$} \\
\hline & Immersing time & 0.4625 & $0.6022^{\text {ns }}$ & 0.463 & $0.0277^{\star}$ & & \\
\hline & Days of death & 1.6438 & $0.0396^{\star}$ & 2.903 & $0.0001^{\star \star}$ & & \\
\hline \multirow{2}{*}{$\begin{array}{c}\text { \%Reduction } \\
\text { entrance } \\
\text { holes }\end{array}$} & Concentration & 8.1739 & $0.0001^{* \star}$ & 8.174 & $0.0001^{\star \star}$ & \multirow{2}{*}{99.2} & \multirow{2}{*}{$0.0001^{\star *}$} \\
\hline & Immersing time & 0.4953 & $0.7672^{\text {ns }}$ & 0.495 & $0.0021^{\star \star}$ & & \\
\hline \multirow{2}{*}{$\begin{array}{c}\text { \%Reduction } \\
\text { emergence } \\
\text { holes }\end{array}$} & Concentration & 8.2235 & $0.0001^{\star \star}$ & 8.224 & $0.0001^{\star *}$ & \multirow{2}{*}{98.9} & \multirow{2}{*}{$0.0001 * *$} \\
\hline & Immersing time & 0.5351 & $0.7510^{\text {ns }}$ & 0.535 & $0.0051^{\star \star}$ & & \\
\hline $\begin{array}{c}\text { Lost wood } \\
\text { weight }\end{array}$ & Concentration & -1.8348 & $0.0001^{* *}$ & \multicolumn{4}{|c|}{-} \\
\hline
\end{tabular}

Previous results on lost wood weight indicated that the loss wood weight decreased with increase concentrations of sodium fluoride and copper sulfate salts, where reduction of infestation percentage was increased with increase of concentration, in same time emergence of beetles was decreased with increasing of salt concentration.

Statistical analysis for obtained values of effect copper sulfate (Table 5) appeared high significant effect for salt concentration on lost wood weight $(P=0.0001)$, the simple regression was negative $(b=-1.8348)$, Table (5).

\section{REFERENCES}

Abbott, W.S. (1925). A method for computing the effectiveness of an insecticide. J.Econ.Entomol.18:265-277

Abd-Allah, F.F and A.W.Tadrous (1995): Biological aspects of Enneadesmus trispinosus Oliv .(Coleoptera : Bostrichidae) on data palm leaves in Egypt. Egypt. J. Agric. Res. 73 (2): 359389. 
Abd El-Latif, N.A., F.F. Mostafa and H.R.K. Ali (2014). Efficiency of certain chemical compounds on the infestation of some wood species by subterranean sand termite, Psammotermes hybostoma Desneux at Fayoum governorate, Egypt. Minufiya J.Agric.Res.39.2 (2):747-757.

Abd-El-Malak, N.N. (2002). Studies on unconventional methods for the control of dry-wood termites. Ph.D. Thesis, Fac. of Agric. Moshtohor Zagazig Univ. Egypt

Abdel Nur, H.A. (1980). The natural durability of building wood and use of wood preservatives in the Sudan. Sociobiology, 5(2); 175-182.

Batt, A.M. and G.N. Girgis (1996). Certain studies on borers attacking data palm trees in Egypt. Menofiya J. Agric. Res. 21 (4): 945-954.

Batt, A.M., A.M. Okil, G.N. Girgis and S.M. Haggag (1996). Biological and ecological study of date palm fronds borer, Phonapate frontalis Fahr., on mango trees in Egypt Fayoum J. Agric. , Res. \& Dev. 10 (1): 156-162.

Batt, A.M. and M.S. Ahmed (2013). Toxicity of some plant extracts to wood powder post beetles, Sinoxylon sudanicum Lesne. (Bostrychidae : Coleoptera). Egypt J. Agric. Res. 91 (3): 959-974.

Chen, G.C., G.R. Esenther and R.M. Rowell (1986). Termite resistance of wood treated with Copper II-compound derived from tri-and dialkylamine-bored complex. Forest Prod. J. 36(5): 18-20.

El-Sabay, Y. (1995). Studies on wood preservation against certain wood borer attack. Egypt J. Agric. Res., 73((1): 83 94.
Gay, F.J., K.M. Harrow and A.H. Wetherly (1958). Laboratory studies of termite resistance.III-A comparative study of the anti-termitic value of boric acid, zinc chloride and "Tantalith U". CSiRO Div. of Entomol. Austalia Technical Pa-per 4, 114.

Haggag, S.M. and A.M. Batt (2000). Biolgogical and ecological studies on the lyctid beetle, Lyctus impressus Lom. (Coleoptera: Lyctidae) on citrus trees. Egypt J. Agric.Res., 78((1): $79-89$.

Kerner, G.W. and G. Becker (1969). Influence of mould fungi on untreated wood particle boards .Material $U$. organism Beih 2: 73-79.

Moein S.I. and R.M. Farrag (1997). Efficacy of some organic salts against the drywood termite Cryptotermes brevis Walker. Egypt J. Agric. Res., 95(3)646651.

Mohamed, M.H. (2013). Biological, ecological and control studies on some wood tree borers in Egypt. Ph.D. Thesis. Fac. Agric. Al-Azhar Univ. Cairo, 123pp.

Pantua, P.C. (1995). Study of termite resistance of foreign chipboard treated with boric acid and other compounds. Forest leaves. Univ. of Phillipines Laguna. Phillipines 14:51-58

Salmen, A.G.A. and A.A. Sayed (1990). Construction techniques for the control of the sand termite Psammotermes hybostoma Desneux in traditional housing in Egypt. Tropical pest management 36 (1): 68-70.

SAS institute (2001). Version 8.02.SAS Institute, Cary, N C. 
التأثير الوقائى والسام لبعض الأملاح المعدنية على خنفساء جريد النخيل

Enneadesmus trispinosus Oliv.(Coleoptera : Bostrychidae)

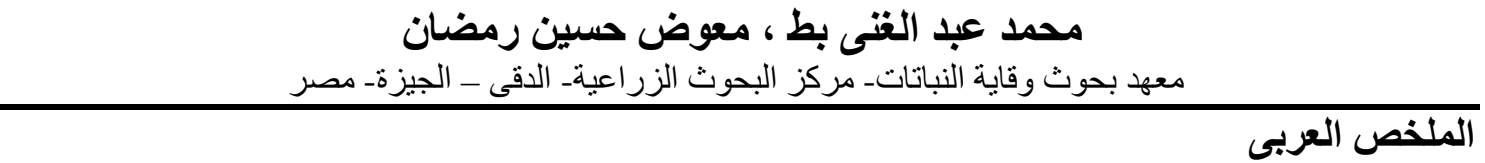

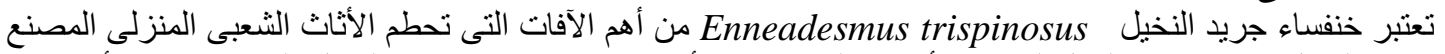

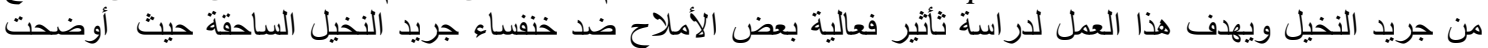

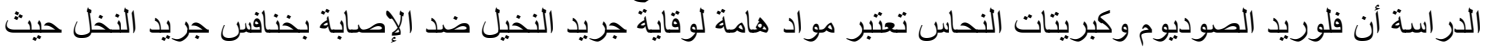

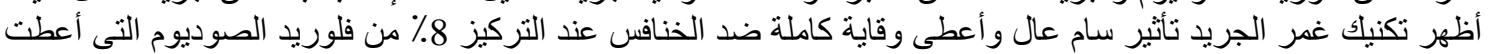

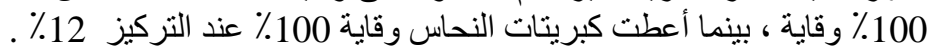

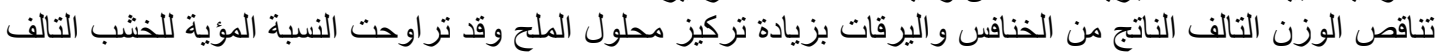

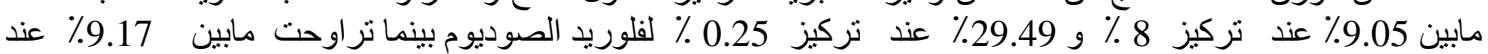

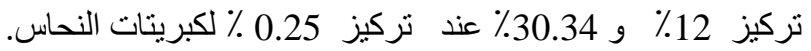

